\title{
The Reflection of Physics Pre-Service Teacher Anxiety in Teaching
}

\author{
Partono $^{1}$, Friska Octavia Rosa ${ }^{2}$ \\ ${ }^{1,2}$ Faculty of Teacher Training and Education, Muhammadiyah University of Metro, Lampung, Indonesia \\ Corresponding Author: Friska Octavia Rosa
}

\begin{abstract}
The study in this research is aimed to see the description of anxiety on teacher candidates based on direct experiences encountered during the teaching practice at school. Many factors causing a teacher candidate to experience anxiety, including cognitive domain, somatic domain, and pedagogic domain factors. This study used a qualitative method with phenomenological approach. Subject used in the study were selected by using the purposive sampling technique, in which teacher candidates are those who have passed the micro-teaching prerequisite subject. The reflection analysis results of teachers candidates indicate that they experienced anxiety during their initial activities at school. Teacher candidates lost the feeling as the time passed and when they have adapted to the environment and condition of students. Some discovered reasons have caused anxiety on teacher candidates when they conduct direct teaching practices in class, such as getting anxious about not being able to deliver materials properly according to the pre-made plans in the learning implementation plan (PPL) and getting anxious about not being able to be a good teacher. Reflection results provide an illustration of how the correlation among psychological factors also needs to be considered in preparing teacher candidates who are ready to directly implement learning in class. This condition indicates the need for in-depth and comprehensive studies regarding psychological factors, and can be made as the evaluation material for education providers of teacher candidate to put their attention on this matter.
\end{abstract}

Keywords: anxiety, teaching practice, physics

\section{INTRODUCTION}

Educators are the learning source for their students (Westbroek et al., 2019; Zhu et al., 2018); a term in which the meaning is undeniable. Competencies of an educator will become the basis of what will be absorbed by the learners (Cofré et al., 2014; Serin, 2018). One of the things that needs to be done in preparing a good competency as a teacher is in the lecture. For teacher candidates, having a high self-esteem is mandatory (Fernández, 2010; Lavasani \& Khandan, 2011; Loughran, 2002). This trait is an attribute which indicates that a teacher candidate is ready to jump directly into the real learning process in class, and affect how the learning outcome of students would become. One of the affecting and determining factors of student achievement is the factor of a teacher. Teachers are creators (Fernández, 2010; Liepertz \& Borowski, 2019; Serin, 2018) of learning process who design the way to obtain maximum results in studying. Duties of teacher are started from formulating learning materials; class management; instructional strategies and techniques; mastering learning materials; communication skills. Therefore, competencies that have to be conceived by a teacher must to be studied and practiced by university students, so they will be able of mastering such skills and become professional educators.

Students of undergraduate education program, physics education department in particular, are students who are projected to 
become physics teachers after they graduate. These graduates are prepared in such a way to acquire competencies mandatory to a teacher regarding learning theories, proficiency and mastery of physics materials, and skills in developing a learning curriculum that is adjusted to the needs of their students in the future. The program associated with this matter is Field Experience Program (PPL). PPL is internship activities done by college students in schools for a couple of months in which learning activities are done directly as a teacher. Teacher candidates experience anxiety in teaching (Arsal, 2014; Kridiotis \& Van Wyk, 2019; Mergler \& Tangen, 2010) because they have not been capable of teaching physics and developing learning materials. Based on the facts acquired by the researcher while observing peer teaching, micro teaching, and teaching practice in the partner school, there were students of physics education department who experienced physical anxiety during the teaching practice. Considering the importance of pedagogic skills (Kilic, 2010; Parker \& Heywood, 2013) that must be mastered by physics teacher candidates, thus, pedagogic is the additional domain that needs to be done by the researcher to assess the anxiety in teaching physics. This study was conducted to reveal the anxiety of teacher candidates in teaching physics during the teaching practice in class by referring to somatic, cognitive, and pedagogic domains.

\section{MATERIALS \& METHODS}

This study aimed to discover the anxiety of teacher candidates in performing direct teaching in class. This study was conducted by directly observing physics learning in class to inspect teacher candidates' anxiety. The researcher observed, appreciated, and interpreted teaching activities of teacher candidates during the PPL in class. Observation was aimed to obtain in-depth comprehensions regarding the anxiety of teacher candidates in physics learning. This study used a qualitative method with phenomenological approach. Phenomenology is the science that describes what is true, and encountered by individuals in their awareness and direct experience. The researcher used the phenomenology approach to uncover the anxiety of teacher candidates in teaching, therefore, the researcher conducted a direct study in physics class to be able of constructing and describing what happens in the learning process.

\section{Research Subject}

Subjects of the study were selected through the purposive sampling technique. Subjects in the study were teacher candidates of physics education with criteria of passing micro teaching subject and will undergo PPL subject. Teacher candidates conducted class teaching activities in the partner school. Interviews were conducted towards five selected teacher candidates. The physics teacher candidates were chosen based on their exam results in micro teaching subject, and indicated as having anxiety in teaching.

\section{Data Collecting}

This study collected data by doing interview, documentation, and observation. The researcher played a role as the main instrument that will discover data and information from teacher candidates regarding their anxiety in teaching through interview and observation, which later be substantiated by documentation results.

\section{Data Analysis}

The data analysis of this study was adopted from Moustakas with the following stages: 1) Describing experiences by considering that every statement is correlated significantly; 2) Relevant records of information; 3) Non-repetitive and nonoverlapping list of questions; 4) there are correlation and categorization of units of invariant meanings into themes; 5) Synthesizing units of invariant meanings and themes into a description of experiences; 6) Reconsidering personal 
written descriptions; 7) Creating texturalstructural descriptions of meaning and essence of your experience.

To ensure the validity of research data of the study, several data validity tests were conducted so valid data were acquired. The data validity in the study consisted of credibility or internal validity with the triangulation method, i.e., observation, interview, and documentation techniques. Transferability of external validity, and dependability of reliability. Dependability was conducted by auditing all study process that have been done.

\section{RESULT \& DISCUSSION}

Figure 1 indicates the initial condition of teacher candidates' anxiety level in small-group teaching as the prerequisite subject before following the PPL activities directly at schools. This result was made as the basis in determining the research subject. Five students passed according to the observation and recording result of micro teaching activities, however, they looked anxious in doing physics teaching. These five teacher candidates were made as the research subject further to discover the anxiety in doing physics teaching directly in class.

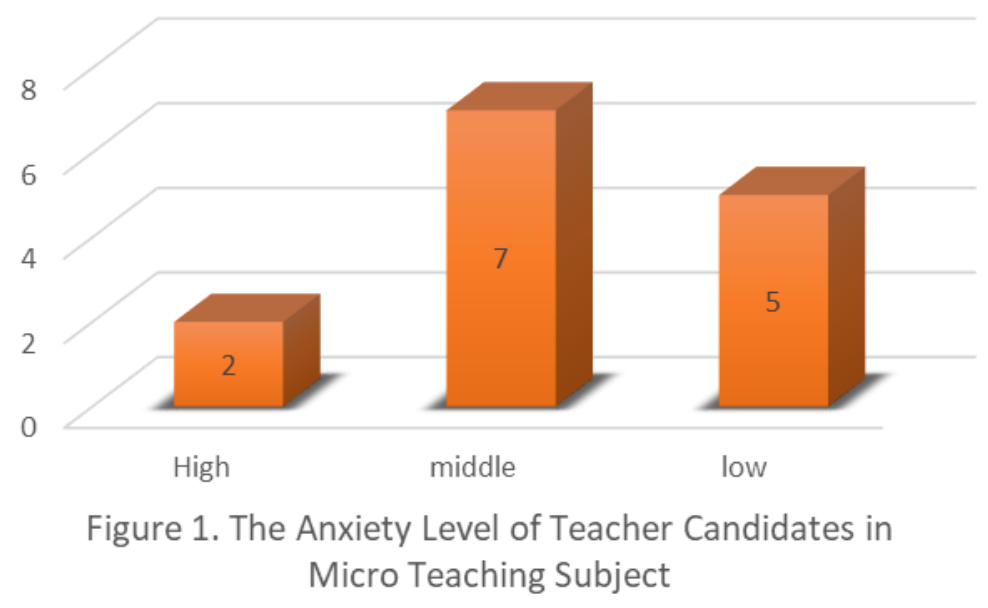

The results of previous studies (Kelly et al., 2020; McMinn \& Aldridge, 2020; Yanti et al., 2019) concluded that teacher candidates who have anxiety during teaching will tend to teach in classically and deliver materials in a shorter period. The anxiety of teacher candidates (Caliskan, 2017; González et al., 2017) can be analyzed from some domains, namely somatic, cognitive, and pedagogic.

This cognitive domain is associated with cognitive changes (Cofré et al., 2014; Fernández, 2010) of an individual when he is faced with physics. The observation was conducted in the learning process in class when teacher candidates were teaching. The delivery of preplanned physics materials in the learning process was shorter than the planning's time. The cognitive domain can also be seen from several aspects, such as concerned about the competencies owned, the confusion encountered during the start of teaching practice, the inability to think clearly or forget things that one often remembers, and recalling failure memories that once experienced in the previous teaching practices (Caliskan, 2017; Jennings et al., 2017; McMinn \& Aldridge, 2020).

In this case, before doing the PPL, teacher candidates have completed the subject of knowledge concentration on physics science and have conducted micro teaching. These subjects are the prerequisite to do PPL. In terms of skills, teacher candidates have been sufficiently prepared and valued as having competencies. However, in the implementation, anxiety still occurs in this domain. Results of the 
interview towards teacher candidates referred to the low confidence in the readiness of each teacher candidate should students ask about materials they have yet to prepare. This condition is an anxiety about the capability of teacher candidates themselves despite passing the theoretical exam in lectures. Mental preparedness became the factor affecting the cognitive domain. The following is a snippet of interview results of teacher candidates.

“....this is my first real experience of teaching students in class. Prior to this, I only used conditioned classes with my friends (physics students) acted as the student. It must be nerve-wracking, I get confused with how I should start, I'm also afraid that the students will find my explanation as hard to understand....."

People are inseparable from anxiety, which is a manifestation of psychological stress (Caliskan, 2017). Anxiety is an indication of one of the occurring psychological disorders (Jennings et al., 2017). A stressful condition may sometimes generate shortness of breath, insomnia, excessive sweating, nervous, even chest pain, headaches, and cold sweats. Heartbeat may also increase if anxiety happens. In this context, one of the causes of anxiety is the emergence of insecurity (Horgan et al., 2018; Jennings et al., 2017; Kelly et al., 2020) due to entering a very new situation, for instance, when one is faced with challenges.

In this case, teacher candidates may potentially experience such an issue because they are faced with a new situation that forces them to jump directly to teach in the presence of a senior teacher that works as an observant and assessor. This condition is certainly aggravating the conditions of teacher candidates to be more distressed and feel less comfortable. Anxiety is physical and emotional responses of someone when he anticipates the occurrence of a situation, both real and imaginary. Before entering the class, the anxiety whether the learning process will run according to the premade plan or not, and student's condition of teacher candidates still can not be predicted. These aspects generate anxiety in teacher candidates in the form of excessive imagination.

PPL program is conducted by teacher candidates in schools for three months (a minimum of eight meetings in class), this will definitely provide good experiences for them. Interview results regarding the PPL program closing also indicated the decreasing level of anxiety level of teacher candidates. Adapting with school environment and class condition is the challenge for teacher candidates to start their activity. Teacher candidates have been accustomed with the class condition and school environment, therefore, they are comfortable and confident, and dismissed the burden and stress within them.

"....I am used to, I already knew student's condition in class. Yes, I still feel nervous when I am about to enter the class. Every time a teaching schedule comes up, I would relearn the materials (physics) to be more confident..."

This trend is certainly positive for teacher candidates who have low anxiety in the beginning of the program. Teacher candidates can regulate the anxiety they have by gradually adapting and identifying the environmental and student conditions. This somatic domain is related to physiological conditions of teacher candidates during the teaching practice, such as trembling, shortness of breath, heart beats faster and dry mouth. In this case, the observation results showed that some teachers were seen to open the learning with a slightly trembling voice, and a faster speaking rhythm compared to the normal condition.

"... when opening the class, my heart is rushing in the beginning, hands feel cold with a little trembling. But I am used to it after several meetings. I became calmer, because I have been used to the students..."

The pedagogic domain is associated with the attitude of students regarding their ability in planning and implementing the learning (Caliskan, 2017; Lavasani \& 
Khandan, 2011; Ünlü, 2018), which consisted of some behaviors, such as formulated the Learning Plan properly before the teaching practice, discovering the learning model that is compatible with the characteristic of materials during the teaching practice, creating interesting learning media that are suitable with learning materials, anxious about doing learning activities.

Educators have crucial roles (Donnelly \& Fitzmaurice, 2011; Rosa et al., 2019; Ünlü, 2018; Yanti et al., 2019) in delivering comprehensive understanding regarding universe. Physics is a subject that plays a crucial role for students to have comprehensive understanding regarding the universe or their environment. The comprehension will generate knowledge that can be used to improve student's proficiency in exploring the surrounding nature (Cofré et al., 2014; Rosa et al., 2019). However, the failure in learning process and the delivery of materials will negatively affect the understanding about physics. This will become the trigger of anxiety in teacher candidates (Serin, 2018).

Apperceptions that occur in teacher candidates encompass the anxiety about being unable to implement the learning model properly according to the stages in conducting teaching practice, getting anxious in explaining learning materials, getting anxious if students start ask questions, getting anxious in concluding the learning materials that have been conveyed, creating the assessment instrument according to the Indicators of Competency Achievement, getting anxious if students can not answer the given question. Such conditions will definitely affect a teacher candidate when he teaches in class. The teacher candidates were not confident with their preparations, however, based on the observation result this issue only occurred during earlier meetings (two to three meetings in average). The feelings of anxiety, embarrassment, unexcited, or desperation will affect the achievement result towards the negative direction. The pleasure of a teacher in teaching a subject will generate creative teaching methods.

\section{CONCLUSION}

The reflection in this study indicates that teacher candidates experienced anxiety in the earlier days of the PPL program and in-class teaching. However, as the time passed, the anxiety is getting less after they adapted with the school environment and students. Another anxiety they have experienced was when they were faced with the teaching assignment for the first time before the students. Of the reflection results, various reasons related to the anxiety during in-class teaching for the first time have been discovered, such as getting anxious about not being able to deliver materials properly and getting anxious about not being able to be a good teacher. This preliminary study implies the need of in-depth and comprehensive studies regarding psychological factors faced by teacher candidates when they conduct in-class teaching, so the factors can be made as the evaluation by the institution (campus) to put their attention on the preparedness of teacher candidates before following the PPL program in the future. The reflection results of the study provide descriptions about psychological condition of teacher candidates that will conduct field activities in terms of teaching at school. Reflective activities are needed for teacher candidates to be made as a habit, so teacher candidates can establish a character that is ready to face field demands with changing conditions and situations.

Acknowledgement: None

\section{Conflict of Interest: None}

\section{Source of Funding: None}

\section{REFERENCES}

1. Arsal, Z. (2014). Microteaching and preservice teachers' sense of self-efficacy in teaching. European Journal of Teacher Education, 37(4), 453-464. 
https://doi.org/10.1080/02619768.2014.912 627

2. Caliskan, S. (2017). Physics Anxiety of PreService Teachers and Their Self-Efficacy Beliefs: Differences According To Gender and Physics. Journal of Baltic Science Education, 16(5), 678-693.

3. Cofré, H., Vergara, C., Lederman, N. G., Lederman, J. S., Santibáñez, D., Jiménez, J., \& Yancovic, M. (2014). Improving Chilean In-service Elementary Teachers' Understanding of Nature of Science Using Self-contained NOS and Content-Embedded Mini-Courses. Journal of Science Teacher Education, 25(7), 759-783. https://doi.org/10.1007/s10972-014-9399-7

4. Donnelly, R., \& Fitzmaurice, M. (2011). Towards productive reflective practice in microteaching. Innovations in Education and Teaching International, 48(3), 335-346. https://doi.org/10.1080/14703297.2011.593 709

5. Fernández, M. L. (2010). Investigating how and what prospective teachers learn through microteaching lesson study. Teaching and Teacher Education, 26(2), 351-362. https://doi.org/10.1016/j.tate.2009.09.012

6. González, A., Fernández, M. V. C., \& Paoloni, P. V. (2017). Hope and anxiety in physics class: Exploring their motivational antecedents and influence on metacognition and performance. Journal of Research in Science Teaching, 54(5), 558-585. https://doi.org/10.1002/tea.21377

7. Horgan, K., Howard, S., \& GardinerHyland, F. (2018). Pre-service Teachers and Stress During Microteaching: An Experimental Investigation of the Effectiveness of Relaxation Training with Biofeedback on Psychological and Physiological Indices of Stress. Applied Psychophysiology Biofeedback, 43(3), 217225. https://doi.org/10.1007/s10484-0189401-9

8. Jennings, P. A., Brown, J. L., Frank, J. L., Doyle, S., Oh, Y., Davis, R., Rasheed, D., Deweese, A., Demauro, A. A., Cham, H., Greenberg, M. T., Impacts, F., Jennings, P. A., Brown, J. L., Frank, J. L., Doyle, S., Davis, R., \& Greenberg, M. T. (2017). Impacts of the CARE for Teachers Program on Teachers' Social and Emotional Competence and Classroom Interactions. Journal of Educational Psychology. https://doi.org/http://dx.doi.org/10.1037/edu 0000187

9. Kelly, S., Romero, A., Morrow, J. A., Denton, Z., \& Ducking, J. (2020). Instructor Misbehaviors and Math Anxiety. Communication Reports, 33(1), 27-40. https://doi.org/10.1080/08934215.2019.167 5737

10. Kilic, A. (2010). Learner-Centered Micro Teaching in Teacher Education. International Journal of Instruction, 3(1), 77-100.

11. Kridiotis, C. A., \& Van Wyk, C. (2019). A critical reflection by participants on microteaching as a learning experience for newly appointed health professions educators. African Journal of Health Professions Education, 11(2), 41. https://doi.org/10.7196/ajhpe.2019.v11i2.11 03

12. Lavasani, M. G., \& Khandan, F. (2011). Exploring Grade R teachers' mathematics curriculum practices and strategies for improvement: Implications for physics teaching. Cypriot Journal of Education, 2(1), 61-74. https://doi.org/https://doi.org/10.18844/cjes. v16i1.5523

13. Liepertz, S., \& Borowski, A. (2019). Testing the Consensus Model: relationships among physics teachers' professional knowledge, interconnectedness of content structure and student achievement. International Journal of Science Education, 41(7), 890-910. https://doi.org/10.1080/09500693.2018.147 8165

14. Loughran, J. J. (2002). Effective reflective practice in search of meaning in learning about teaching. Journal of Teacher Education, 53(1), 33-43. https://doi.org/10.1177/0022487102053001 004

15. McMinn, M., \& Aldridge, J. (2020). Learning environment and anxiety for learning and teaching mathematics among preservice teachers. Learning Environments Research, 23(3), 331-345. https://doi.org/10.1007/s10984-019-09304-y

16. Mergler, A. G., \& Tangen, D. (2010). Using microteaching to enhance teacher efficacy in pre-service teachers. Teaching Education, 21(2), 199-210. https://doi.org/10.1080/1047621090299846 6 
17. Parker, J., \& Heywood, D. (2013). Exploring How Engaging With Reflection on Learning Generates Pedagogical Insight in Science Teacher Education. Science Education, 97(3), 410-441. https://doi.org/10.1002/sce.21049

18. Rosa, F. O., Mundilarto, Wilujeng, I., \& Sulistyani, A. M. (2019). Science in everyday life to build science literacy. International Journal of Scientific and Technology Research, 8(12), 1148-1151.

19. Serin, H. (2018). A Comparison of TeacherCentered and Student-Centered Approaches in Educational Settings. International Journal of Social Sciences \& Educational Studies, 5(1), 164-167. https://doi.org/10.23918/ijsses.v5i1p164

20. Ünlü, M. (2018). Effect of micro-teaching practices with concrete models on preservice mathematics teachers' self-efficacy beliefs about using concrete models. Universal Journal of Educational Research, 6(1), 68-82. https://doi.org/10.13189/ujer.2018.060106

21. Westbroek, H., De Vries, B., Walraven, A., Handelzalts, A., \& McKenney, S. (2019).
Teachers as co-designers: Scientific and colloquial evidence on teacher professional development and curriculum innovation. In Collaborative Curriculum Design for Sustainable Innovation and Teacher Learning. https://doi.org/10.1007/978-3030-20062-6_3

22. Yanti, F. A., Kuswanto, H., Mundilarto, Habibi, \& Rosa, F. O. (2019). Pre-service physics teachers' research activities by research-based learning. Journal of Turkish Science Education, 16(1), 77-84. https://doi.org/10.12973/tused.10267a

23. Zhu, M., Urhahne, D., \& Rubie-Davies, C. M. (2018). The longitudinal effects of teacher judgement and different teacher treatment on students' academic outcomes. Educational Psychology, 38(5), 648-668. https://doi.org/10.1080/01443410.2017.141 2399

How to cite this article: Partono, Rosa FO. The reflection of physics pre-service teacher anxiety in teaching. International Journal of Research and Review. 2021; 8(9): 311-317. DOI: https:// doi.org/10.52403/ijrr.20210941 